\title{
PENERAPAN METODE SIMPLE ADDITIVE WEIGHTING (SAW) DENGAN MODEL FUZZY MODEL ATRIBUTE DECISION MAKING (FMADM) PENILAIAN KINERJA KARYAWAN DTPEDULI BEKASI
}

\author{
Fajar Agustini'; Elien Riris Ariska ${ }^{2}$ \\ Sistem Informasi Akuntansi Kampus Kabupaten Karawang ${ }^{1}$ \\ Universitas Bina Sarana Informatika ${ }^{1}$ \\ fajar.fgt@bsi.ac.id1 \\ Sistem Informasi \\ STMIK Nusa Mandiri² \\ elien.riris123@gmail.com²

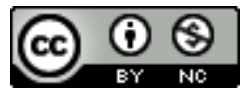 \\ Ciptaan disebarluaskan di bawah Lisensi Creative Commons Atribusi-NonKomersial 4.0 Internasional.
}

\begin{abstract}
Performance assessment of a job in an agency or company is a stage of job evaluation to determine the benchmark in determining the quality and achievement of each employee. In the process even an agency or company has a standard to measure the success of work. With the many service programs and empowerment of the people conducted in DTPeduli Bekasi encourage each employee to provide the best performance of each employee. However, in the development of performance appraisal is done less than the maximum because there is no system support. Results from research Employee performance assessment on DTPeduli Bekasi with some aspects of the criteria using Fuzzy Simple Additive Weighting (FSAW) model has been running well and can generate weighting assessment criteria and information clear and fast compared to the calculation manually so that Branch Head DTPeduli Bekasi can use it as a tool for decision making appropriate in decision making employee performance appraisal in DTPeduli Bekasi.
\end{abstract}

Intisari- Penilaian kinerja terhadap suatu pekerjaan dalam sebuah instansi atau perusahaan merupakan suatu tahap evaluasi kerja untuk mengetahui tolak ukur dalam menentukan kualitas serta pencapaian masing-masing karyawannya. Dalam prosesnya pun sebuah instansi atau perusahaan memiliki standar untuk mengukur keberhasilan kerja. Dengan banyaknya program pelayanan serta pemberdayaan umat yang dilakukan di DTPeduli Bekasi mendorong setiap karyawan untuk memberikan kinerja terbaik dari setiap karyawannya.Namun dalam perkembangannya penilaian kinerja yang dilakukan kurang maksimal karena belum adanya sistem yang mendukung. Hasil dari penelitian
Penilaian kinerja karyawan pada DTPeduli Bekasi dengan beberapa aspek kriteria menggunakan model Fuzzy Simple Additive Weighting (FSAW) sudah berjalan dengan baik dan dapat menghasilkan pembobotan kriteria penilaian dan informasi yang jelas dan cepat dibandingkan dengan perhitungan secara manual sehingga Kepala Cabang DTPeduli Bekasi dapat mempergunakannya sebagai alat bantu pengambilan keputusan yang tepat dalam pengambilan keputusan penilaian kinerja karyawan di DTPeduli Bekasi.

Kata Kunci: Penilaian, Kinerja, FSAW.

\section{PENDAHULUAN}

Penilaian kinerja terhadap suatu pekerjaan dalam sebuah instansi atau perusahaan merupakan suatu tahap evaluasi kerja untuk mengetahui tolak ukur dalam menentukan kualitas serta pencapaian masing-masing karyawannya. Dalam prosesnya pun sebuah instansi atau perusahaan memiliki standar untuk mengukur keberhasilan kerja (Abadi \& Latifah, 2016). Untuk itu dibutuhkan SDM (sumber daya manusia) yang berkualitas sebagai salah satu faktor yang menunjang dalam meningkatkan produktivitas kinerja (Mudayana, 2013). Selain itu SDM (sumber daya manusia) yang memiliki keterampilan (skill) yang baik juga dapat meningkatkan prestasi kerja seorang karyawan. DT Peduli Bekasi merupakan sebuah lembaga amil zakat nasional dan merupakan lembaga nirlaba yang bergerak dibidang penghimpunan zakat, infaq, shodaqoh dan wakaf (ZISWAF). Hasil penghimpunan dana ZISWAF tersebut selanjutnya digulirkan kepada mustahik dalam bentuk program pelayanan dan pemberdayaan umat 
dalam bidang ekonomi, kesehatan, pendidikan dan social charity serta dikemas secara kreatif, berkarakter BAKU (baik \& kuat), memandirikan serta berkesinambungan. Dengan banyaknya program pelayanan serta pemberdayaan umat yang dilakukan di DTPeduli Bekasi menuntut setiap karyawan untuk memberikan kinerja terbaik dari setiap karyawannya. Namun dalam perkembangannya penilaian kinerja yang dilakukan kurang maksimal karena faktor-faktor yang mempengaruhi kinerja karyawan tersebut seperti: lingkungan kerja, kepemimpinan, disiplin kerja, komunikasi, motivasi kerja, dan fasilitas (Ardila \& Pramusinto, 2015). Dalam pelaksanaan tugas karyawan di DTPeduli masih tumpang tindih, beberapa karyawan tidak bekerja sesuai dengan SOP yang sudah diterapkan di DTPeduli. Hal ini membuat manajemen perlu mengambil keputusan untuk melakukan penilaian kinerja karyawan guna keberlangsungan DTPeduli.
Metode Simple Additive Weighting (SAW) merupakan salah satu model yang dapat digunakan pada proses pengambilan keputusan dengan metode penjumlahann terbobot, salah satunya dalam penilaian kinerja karyawan. Metode Simple Additive Weighting (SAW) digunakan untuk mencari nilai tertinggi dari setiap kriteria berdasarkan bobot yang sudah ditentukan dan membantu dalam menetapkan prioritas yang selama ini belum akurat (Djamain, Y., \& Christin, 2015). Fuzzy Multiple Attribute Decision Making adalah suatu metode yang digunakan untuk mencari alternatif optimal dari sejumlah alternatif dengan kriteria tertentu. Inti dari Fuzzy Multiple Attribute Decision Making adalah menentukan nilai bobot untuk setiap atribut, kemudian dilanjutkan dengan proses perankingan yang akan menyeleksi alternatif yang sudah diberikan(Rusdiansyah, 2017).

\section{Penelitian Terkait}

\begin{tabular}{|c|c|c|c|c|}
\hline No & Topik/Judul & Penulis & Metode & Hasil/Kesimpulan \\
\hline 1 & $\begin{array}{l}\text { Sistem Pendukung } \\
\text { Keputusan Untuk } \\
\text { Pemilihan Karyawan } \\
\text { dengan Metode Simple } \\
\text { Additive Weightingdi PT. } \\
\text { Herba Penawar Alwahida } \\
\text { Indonesia }\end{array}$ & $\begin{array}{l}\text { Ardhi Bagus } \\
\text { Primahudi, } \\
\text { Fajar } \\
\text { Agustinus } \\
\text { Suciono, } \\
\text { Anang Aris } \\
\text { Widodo-2016 }\end{array}$ & $\begin{array}{l}\text { Simple Additive } \\
\text { Weighting } \\
(S A W)\end{array}$ & $\begin{array}{l}\text { Penelitian ini bertujuan untuk membantu perusahaan } \\
\text { dalam pemilihan karyawan terbaik pada PT. Herba } \\
\text { Penawar Alwahida Indonesia serta untuk } \\
\text { menghasilakan sistem pendukung keputusan pemilihan } \\
\text { karyawan terbaik berdasarkan ranking menentukan } \\
\text { karyawan terbaik di PT. Herba Penawar Alwahida } \\
\text { Indonesi system menggunakan kriteria-kriteria yang } \\
\text { sudah digunakan di perusahaan tersebut yaitu } \\
\text { pendidikan terakhir, IPK, usia,pengalaman kerja, } \\
\text { akreditasi, status perkawinan dan kesesuaian program } \\
\text { studi pelamar kerja.sistem ini dikembangkan dengan } \\
\text { bahasa pemrograman PHP dan XAMPP. }\end{array}$ \\
\hline 2 & $\begin{array}{l}\text { Decision Support System } \\
\text { PenilaianKinerja } \\
\text { Karyawanpada } \\
\text { Perusahaan menggunakan } \\
\text { Metode Simple Additive } \\
\text { Weighting(SAW)Weighting } \\
(\text { SAW })\end{array}$ & $\begin{array}{l}\text { Satria Abadi, } \\
\text { Febriani } \\
\text { Latifah-2016 }\end{array}$ & $\begin{array}{l}\text { Simple Additive } \\
\text { Weighting } \\
(S A W)\end{array}$ & 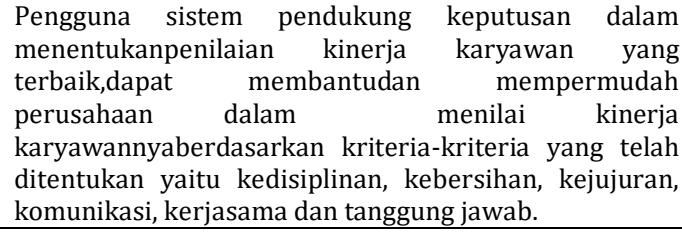 \\
\hline 3 & $\begin{array}{l}\text { Sistem Pendukung } \\
\text { Keputusan Penilaian } \\
\text { Kinerja Karyawan } \\
\text { menggunakan Metode } \\
\text { Simple Additive } \\
\text { Weighting(SAW) pada } \\
\text { PT. Indonesia Steel Tube } \\
\text { Work }\end{array}$ & $\begin{array}{l}\text { (Siprianus } \\
\text { Endro Sri } \\
\text { Widodo, } \\
\text { Septia Lutfi, } \\
\text { 2014) }\end{array}$ & $\begin{array}{l}\text { Simple } \\
\text { Additive } \\
\text { Weighting } \\
(S A W)\end{array}$ & $\begin{array}{l}\text { Sistem pendukung keputusan ini dapat melakukan } \\
\text { proses perhitungan penilaian kinerja karyawan } \\
\text { dengan laporan obyektif dan adil berdasarkan } \\
\text { mewujudkan penilaian yangperankingan, sehingga } \\
\text { dapathasil kriteria yang ada.Perhitungan pada sistem } \\
\text { ini menggunakan }\end{array}$ \\
\hline 4 & $\begin{array}{l}\text { Sistem Penunjang } \\
\text { Keputusan Kelulusan } \\
\text { Peserta Prajabatan } \\
\text { menggunakan Metode } \\
\text { Simple Additive } \\
\text { Weighting(SAW) pada } \\
\text { Pusat Perkembangan } \\
\text { Teanga Kependidikan }\end{array}$ & $\mathrm{i}, 2015)$ & $\begin{array}{l}\text { Simple } \\
\text { Additive } \\
\text { Weighting } \\
(S A W)\end{array}$ & $\begin{array}{l}\text { Pembuatan Sistem Penunjang Keputusan (SPK) } \\
\text { untuk melakukan perhitungan sebagai penyeleksi } \\
\text { data dengan hasil perankingan. Sistem yang telah } \\
\text { dibuat mengacu pada rumusan masalah yang ada } \\
\text { yaitu sistem dapat menyeleksi data sesuai ketentuan } \\
\text { dengan melakukan perhitungan berdassarkan metode } \\
\text { Simple Additive Weighting(SAW) pada Fuzzy } \\
\text { Multiple Attribute Decision Making (FMADM). }\end{array}$ \\
\hline 5 & $\begin{array}{l}\text { Sistem Penilaian dan } \\
\text { Perankingan Karyawan } \\
\text { pada Radar Banjarmasin } \\
\text { denagn menggunakan } \\
\text { Metode Simple Additive } \\
\text { Weighting }\end{array}$ & $\begin{array}{l}\text { (Yahya \& } \\
\text { Yudihartanti, } \\
\text { n.d.) }\end{array}$ & $\begin{array}{l}\text { Simple } \\
\text { Additive } \\
\text { Weighting } \\
\text { (SAW) }\end{array}$ & $\begin{array}{l}\text { Dari hasil penelitian maka didapat perbandingan } \\
\text { data pretest danposttest yaitu pada posisi wartawan } \\
\text { dengan } 27 \text { data sevesar } 96,70 \% \text { ranking tidak sesuai } \\
\text { dan } 3,30 \% \text { ranking sesuai, pada posisi redaktur } \\
\text { dengan } 7 \text { data sebesar } 71,43 \% \text { ranking tidak sesuai } \\
\text { dan } 28,57 \% \text { pada posisi layouter }\end{array}$ \\
\hline
\end{tabular}




\begin{tabular}{|c|c|c|c|c|}
\hline 6 & $\begin{array}{l}\text { Sistem Pendukung } \\
\text { Keputusan Penentuan } \\
\text { Kontrak Kerja Agent } \\
\text { Call Center } \\
\text { menggunakan metode } \\
\text { SAW }\end{array}$ & $\begin{array}{l}\text { (Sheyla Feby } \\
\text { Liesdiana, } \\
\text { 2017) }\end{array}$ & $\begin{array}{l}\text { Simple } \\
\text { Additive } \\
\text { Weighting } \\
\text { (SAW) }\end{array}$ & $\begin{array}{l}\text { Penerapan aplikasi sistem pendukung keputusan } \\
\text { penentuan kelanjutan kontrak kerja berdasarkan } \\
\text { penilaian kinerja ini dapat membant dan } \\
\text { mempermudah supervisor call center dalam } \\
\text { melakukan penilaian kinerja, pengolahan data } \\
\text { menjadi lebih cepat dan tepat serta dapat } \\
\text { memberikan keputusan yang objektif dalam } \\
\text { menentukan kelanjutan kontrak kerja agent call } \\
\text { center. }\end{array}$ \\
\hline 7 & $\begin{array}{l}\text { Sistem Pendukung } \\
\text { Keputusan Penerimaan } \\
\text { Pegawai Baru PT.PLN } \\
\text { (Persero) Kantor Pusat } \\
\text { dengan menggunakan } \\
\text { metode Simple Additive } \\
\text { Weighting(SAW) }\end{array}$ & $\begin{array}{l}\text { (Djamain, Y., } \\
\text { \& Christin, } \\
\text { 2015) }\end{array}$ & $\begin{array}{l}\text { Simple } \\
\text { Additive } \\
\text { Weighting } \\
\text { (SAW) }\end{array}$ & $\begin{array}{l}\text { Sistem pendukung keputusan yang dapat dibuat } \\
\text { guna membantu membuat keputusan dalam } \\
\text { penerimaan calon pegawai baru pada PT.PLN } \\
\text { (Persero) Kantor Pusat berdasarkan hasil analisa } \\
\text { sesuai dengan kriteria yang ditentukan. Penerimaan } \\
\text { dilakukan sesuai dengan hasil seleksi Administrasi, } \\
\text { General Aptitude Test (GAT), Akademis dan } \\
\text { Bahasa Inggris, Psikotes dan FGD, Kesehatan dan } \\
\text { wawancara yang dimiliki calon pegawai tersebut }\end{array}$ \\
\hline 8 & $\begin{array}{l}\text { Analisis Keputusan } \\
\text { Menentukan Jurusan } \\
\text { Pada Sekolah Menengah } \\
\text { Kejuruan Dengan } \\
\text { Metode Simple Additive } \\
\text { Weighting }\end{array}$ & $\begin{array}{l}\text { (Rusdiansyah, } \\
\text { 2017) }\end{array}$ & $\begin{array}{l}\text { Smple } \\
\text { Additive } \\
\text { Weighting } \\
\text { (SAW) }\end{array}$ & $\begin{array}{l}\text { Sistem penjurusan dan penerimaan siswa SMK ini } \\
\text { memudahkan panitia penerimaan siswa dalam } \\
\text { mengumpulan data siswa dan menghitung nilai } \\
\text { siswa, Metode Simple Additive Weighting (SAW) } \\
\text { yang digunakan dapat menyeleksi siswa } \\
\text { berdasarkan nilai penentuan jurusan untuk } \\
\text { mendapat siswa yang berkualitas dan sistem } \\
\text { penjurusan dan penerimaan siswa ini bersifat statis, } \\
\text { karena usertidak dapat menambah jurusan dan } \\
\text { kriteria baru. }\end{array}$ \\
\hline 9 & $\begin{array}{l}\text { Metode Simple } \\
\text { Additive Weighting } \\
\text { (SAW)dalam } \\
\text { Penentuan Pemberian } \\
\text { Beasiswa pada Siswa } \\
\text { Sekolah Menengah } \\
\text { Atas }\end{array}$ & $\begin{array}{l}\text { (Susanti \& } \\
\text { Wasiyanti, } \\
\text { 2017) }\end{array}$ & $\begin{array}{c}\text { Simple } \\
\text { Additive } \\
\text { Weighting } \\
\text { (SAW) }\end{array}$ & $\begin{array}{l}\text { Maka hasil akhir yaitu siswa yang berhak } \\
\text { mendapatkan beasiswa KJP (Kartu Jakarta Pintar) } \\
\text { untuk siswa tidak mampu dengan nilai } 2.16,1.77 \text {, } \\
1.69,1.69,1.66,1.66,1.61,1.58,1.53 \text { dan 1.53. } \\
\text { Penentuan penerimaan beasiswa dilakukan } \\
\text { berdasarkan kriteria yang telah ditentukan. Bobot } \\
\text { yang diberikan padasetiap kriteria mempengaruhi } \\
\text { hasil akhir. Dengan adanya analisis dengan } \\
\text { metodeSAW ini dapat menghindari atau } \\
\text { meminimalkan kesalahan dan kecurangan yang } \\
\text { rawan terjadi. }\end{array}$ \\
\hline 10 & $\begin{array}{l}\text { Sistem Pendukung } \\
\text { Keputusan Pemilihan } \\
\text { Laptop yang tepat } \\
\text { menggunakan Simple } \\
\text { Additive } \\
\text { Weighting(SAW) }\end{array}$ & $\begin{array}{l}\text { (Khairul et } \\
\text { al., 2016) }\end{array}$ & $\begin{array}{l}\text { Simple } \\
\text { Additive } \\
\text { Weighting } \\
\text { (SAW) }\end{array}$ & $\begin{array}{l}\text { Berdasarkan uraian masalah dan diskusi dalam bab- } \\
\text { bab sebelumnya, penulis dapat menyimpulkan } \\
\text { bahwa metode Simple Additive Weighting(SAW) } \\
\text { dapat diterapkan dalam menemukan alternatif } \\
\text { keputusan terbaik untuk membeli laptop. } \\
\text { Penerapannya sangat membantu untuk memberikan } \\
\text { informasi kepada konsumen.Mereka dapat memilih } \\
\text { laptop sesuai dengan selera dan kemampua mereka. } \\
\text { Denagn pendekan ini, pengguna dapat menghitung } \\
\text { daya beli barang. }\end{array}$ \\
\hline
\end{tabular}

Sumber: (Agustini \& Ariska, 2018)

\section{BAHAN DAN METODE}

Bahan

Dalam Penelitian ini digunakan data primer yaitu observasi dan wawancara langsung kepada Kepala Cabang DTPeduli Bekasi. Data tersebut merupakan data karyaawan DTPeduli Bekasi sebanyak 25 orang sebagai berikut:

Tabel.1 Daftar Karyawan DTPeduli Bekasi

\begin{tabular}{lll}
\hline No & Nama & Bagian \\
\hline 1. & Karyadi & Kasubag Operasional \\
\hline 2. & Meiga Wati Herlina & Administrasi \\
\hline 3. & Harmi Syaputra & Marketing Retail \\
\hline
\end{tabular}

\begin{tabular}{lll}
\hline 4. & Hanifah Andini & Keuangan \\
\hline 5. & Arif Rahman & Umum \\
\hline 6. & Ujang Sadili & Kabag Marketing \\
\hline 7. & Muhammad Hilman Rifqi & Markom \\
\hline 8. & Haryuda & Kabag Pemberdayaan \\
\hline 9. & Reni Kurnia & Program Ekonomi \\
\hline 10. & Imam Mustaqim & Program Pendidikan \\
\hline 11. & Arman Maulana & Marketing UPZ HI \\
\hline 12. & Esa Nur Khaerurrizal & CRM \\
\hline 13. & Firdaus & TPL Misykat \\
\hline 14. & Faiz Abdillah & Marketing UPZ Kranggan \\
\hline 15. & Anita Hermawati & Lansos \\
\hline 16. & Annisa UI Hasanah Azmi & Program UPZ Kranggan \\
\hline 17. & Lupi Nugraha & Marketing Retail \\
\hline 18. & M. Lutfi Qairawan & Markom \\
\hline
\end{tabular}




\begin{tabular}{lll}
\hline 19. & Aep Syaipudin & Marketing Corporate \\
\hline 20. & Hamzah Syahid Abdillah & Program Dakwah Sosial \\
\hline 21. & Rachmad Andi & Marketing Corporate \\
\hline 22. & Endar Sunandar & Program Dakwah Sosial \\
\hline 23. & Rahayu & CRM \\
\hline 24 & Nurul Khaeriyah & Marketing Retail \\
\hline 25. & M. Husuf & Lansos \\
\hline
\end{tabular}

Sumber: (Agustini \& Ariska, 2018)

\section{Metode}

Penelitian dilakukan di DTPeduli Bekasi dengan membandingkan antara penilaian kinerja karyawan manual dan penilaian kinerja karyawan dengan menggunakan metode Fuzzy Simple Additive Weighting (FSAW) untuk mengetahui seberapa cepat, akurat dan tepat proses perhitungan yang dilakukan.

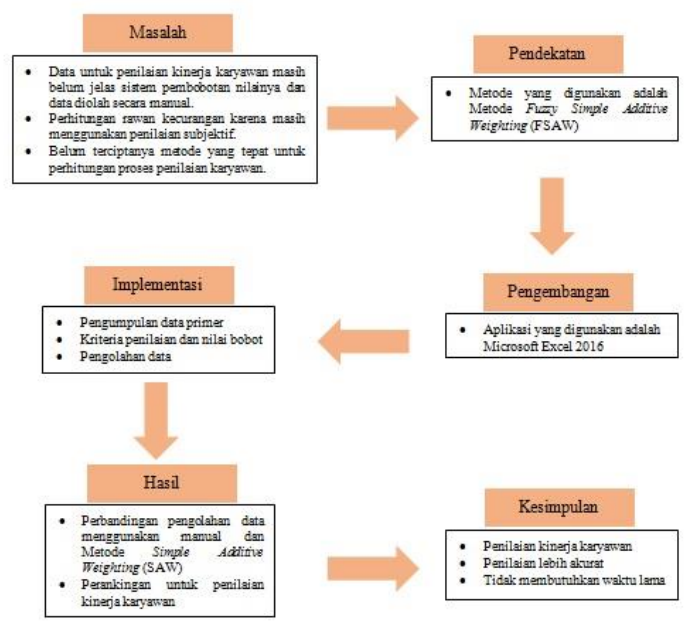

Sumber: (Agustini \& Ariska, 2018)

Gambar1. Bagan Tahapan Penelitian

\section{A. Metode Analisis Data}

Berdasarkan hasil penilaian subjektif dari Kepala Cabang di DTPeduli Bekasi. Metode analisis data yang diperlukan adalah sebagai berikut:

1. Menentukan kriteria penilaian (Ci)

2. Menentukan rating kecocokan setiap alternatif pada setiap kriteria.

3. Membuat matriks keputusan berdasarkan kriteria (Ci); kemudian melakukan normalisasi berdasarkan persamaan yang disesuaikan dengan jenis atribut (Perilaku, Inisisatif, Kerjasama, Disiplin, Loyalitas, Komitmen, Kreatifitas, Tanggung Jawab, Kehadiran, Kekuatan Ruhiyah, Pengetahuan Pekerjaan, Pemahaman Pekerjaan dan Penerapan Pekerjaan) sehingga diperoleh data ternornalisasi R.

4. Hasil akhir diperoleh dari proses perankingan yaitu penjumlahan dari perkalian ternormalisasi $\mathrm{R}$ dengan vektor bobot sehingga diperoleh nilai terbesar yang dipilih sebagai alternatif terbaik (Ai) sebagai solusi. Kriteria- kriteria tersebut dapat dilihat pada tabel berikut:

Tabel . 2.Kriteria Penilaian

\begin{tabular}{lll}
\hline Aspek & \multicolumn{1}{l}{ Sub Aspek } & Kriteria \\
\hline & Perilaku & C1 \\
\cline { 2 - 3 } & Inisiatif & C2 \\
\cline { 2 - 3 } & Kerjasama & C3 \\
\cline { 2 - 3 } Sikap Kerja & Disiplin & C4 \\
\cline { 2 - 3 } & Loyalitas & C5 \\
\cline { 2 - 3 } & Komitmen & C6 \\
\cline { 2 - 3 } & Kreatifitas & C7 \\
\cline { 2 - 3 } & Tanggung Jawab & C8 \\
\cline { 2 - 3 } & Kehadiran & C9 10 \\
\hline \multirow{3}{*}{ Kemampuan Kerja } & Pengetah Ruhiyah & C12 \\
\cline { 2 - 3 } & Pemahaman Pekerjaan & C13 \\
\hline Hasil Kerja & Penerapan Pekerjaan & \\
\hline Sumber: (Agustini \& Ariska, 2018) &
\end{tabular}

Tabel 2. diatas menjelaskan tentang kriteria penilaian yang ada di DTPeduli Bekasi, sebagai acuan penilaian karyawan terbaik.

Tabel. 3 Kriteria Bobot

\begin{tabular}{cc}
\hline Keterangan & $\begin{array}{c}\text { Nilai } \\
\text { Bobot }\end{array}$ \\
\hline Sangat Penting & 0,90 \\
\hline Penting & 0,75 \\
\hline Cukup & 0,50 \\
\hline Tidak Penting & 0,25 \\
\hline Sangat Tidak Penting & 0 \\
\hline
\end{tabular}

Sumber: (Rusdiansyah, 2017)

\section{B. Metode Fuzzy Multiple Attribute Decision} Making (FMADM)

Pada penelitian ini, Inti dari Fuzzy Multiple Attribute Decision Making adalah menentukan nilai bobot untuk setiap atribut, kemudian dilanjutkan dengan proses perankingan yang akan menyeleksi alternatif yang sudah diberikan. Pada dasarnya, ada tiga pendekatan untuk mencari nilai bobot atribut, yaitu pendekatan subyektif, pendekatan objektif dan pendekatan integrasi antara subyektif dan obyektif (Rusdiansyah, 2017).

C. Metode Simple Additive Weighting (SAW) Metode Simple Additive Weighting (SAW) ini mengharuskan pembuat keputusan menentukan bobot bagi setiap atribut. Skor total untuk alternatif diperoleh dengan menjumlahkan seluruh hasil perkalian antara rating (yang dapat dibandingkan lintas atribut) dan bobot tiap atribut. Rating tiap atribut haruslah bebas dimensi dalam arti telah melewati proses normalisasi matriks sebelumnya. Proses normalisasi matriks keputusan menggunakan rumus 1 sebagai berikut: 
$r_{i j}\left\{\begin{array}{l}\frac{X_{i j}}{\operatorname{Max} X_{i j}} \text { Jika } j \text { adalah atribut keuntungan...(1) } \\ \frac{\text { MinX } X_{i j}}{X_{i j}} \text { Jika } j \text { adalah atribut Biaya (cost)......(2) }\end{array}\right.$

Dimana $\mathrm{R}_{\mathrm{ij}}$ adalah rating kinerja ternormalisasi dari alternatif Aipada atribut $\mathrm{Cj}_{\mathrm{j}} ; \mathrm{i}=1,2, \ldots, \mathrm{m}$ dan $j=1,2, \ldots, n$. Nilai preferensi untuk setiap alternatif (Ci) diberikan dengan rumus 2 sebagai berikut:

$V_{i=\sum_{j=i}^{n}} w_{j} r_{j}$

Nilai Vi yang lebih besar mengindikasikan bahwa alternatif $A_{i}$ lebih terpilih.

\section{HASIL DAN PEMBAHASAN}

\section{A. Pengolahan Data FSAW}

Berikut ini adalah langkah-langkah dalam mengolah data yang telah dikumpulkan oleh peneliti menjadi data ranking dengan menggunakan metode FSAW:

\section{Langkah Penyelesaian Metode SAW}

Adapun langkah-langkah penyelesaian masalah dengan metode SAW adalah sebagai berikut:

a. Menentukan kriteria-kriteria yang akan dijadikan acuan dalam pengambilan keputusan, yaitu $\mathrm{Ci}$.

b. Membuat matriks keputusan berdasarkan kriteria ( $\mathrm{Ci}$ ); kemudian melakukan normalisasi berdasarkan persamaan yang disesuaikan dengan jenis atribut (Perilaku, Inisiatif, Kerjasama, Disiplin, Loyalitas, Komitmen, Kreatifitas, Tanggung Jawab, Kehadiran, Kekuatan Ruhiyah, Pengetahuan Pekerjaan, Pemahaman Pekerjaan dan Penerapan Pekerjaan) sehingga diperoleh data ternormalisasi R.

c. Hasil akhir diperoleh dari proses perankingan yaitu penjumlahan dari perkalian ternormalisasi R dengan vektor bobot sehingga diperoleh nilai terbesar yang dipilih sebagai alternatif terbaik $(\mathrm{A} i)$ sebagai solusi.

2. Menentukan kriteria-kriteria yang akan dijadikan acuan dalam pengambilan keputusan, yaitu $\mathrm{C}_{\mathrm{i}}$ Setelah data diperoleh, selanjutnya adalah melakukan perhitungan dengan data tersebut dengan metode FSAW. Untuk menganalisa data penilaian dari pimpinan yang sudah didapatkan dari Kepala Cabang DTPeduli Bekasi, sehinga dapat dilakukan langkahlangkah sebagai berikut:

Tabel. 4 Data Karyawan dan Nilai dari Kepala Cabang

\begin{tabular}{|c|c|c|c|c|c|c|c|c|}
\hline \multirow[b]{2}{*}{0} & \multirow[b]{2}{*}{ NAMA } & \multicolumn{7}{|c|}{ NILAI } \\
\hline & & $\mathrm{C} 1$ & $\mathrm{C} 2$ & C3 & $\mathrm{C} 4$ & $\mathrm{C} 5$ & $\mathrm{C} 6$ & $\mathrm{C} 7$ \\
\hline 1 & Karyadi & 95 & 85 & 95 & 90 & 90 & 80 & 90 \\
\hline 2 & $\begin{array}{l}\text { Meiga Wati } \\
\text { Herlina }\end{array}$ & 90 & 90 & 90 & 80 & 85 & 85 & 80 \\
\hline 3 & $\begin{array}{l}\text { Harmi } \\
\text { Syaputra }\end{array}$ & 90 & 80 & 80 & 80 & 80 & 85 & 75 \\
\hline 4 & $\begin{array}{l}\text { Hanifah } \\
\text { Andini }\end{array}$ & 80 & 85 & 80 & 80 & 75 & 85 & 75 \\
\hline 5 & Arif Rahman & 90 & 80 & 80 & 80 & 85 & 80 & 85 \\
\hline 6 & Ujang Sadili & 80 & 80 & 80 & 75 & 80 & 80 & 90 \\
\hline 7 & $\begin{array}{l}\text { Muhammad } \\
\text { Hilman Rifqi }\end{array}$ & 85 & 85 & 90 & 80 & 90 & 80 & 75 \\
\hline 8 & Haryuda & 85 & 80 & 90 & 80 & 85 & 80 & 75 \\
\hline 9 & Reni Kurnia & 90 & 80 & 90 & 85 & 85 & 80 & 75 \\
\hline 10 & $\begin{array}{l}\text { Imam } \\
\text { Mustaqim }\end{array}$ & 80 & 80 & 85 & 80 & 90 & 85 & 80 \\
\hline 11 & $\begin{array}{l}\text { Arman } \\
\text { Maulana }\end{array}$ & 80 & 80 & 80 & 85 & 75 & 85 & 80 \\
\hline 12 & $\begin{array}{l}\text { Esa Nur } \\
\text { Khaerurrizal }\end{array}$ & 80 & 80 & 80 & 85 & 75 & 85 & 80 \\
\hline 13 & Firdaus & 85 & 80 & 80 & 90 & 80 & 80 & 75 \\
\hline 14 & $\begin{array}{l}\text { Faiz } \\
\text { Abdillah }\end{array}$ & 80 & 80 & 80 & 75 & 80 & 80 & 75 \\
\hline 15 & $\begin{array}{l}\text { Anita } \\
\text { Hermawati }\end{array}$ & 80 & 80 & 80 & 80 & 80 & 85 & 75 \\
\hline 16 & $\begin{array}{l}\text { Annisa UI } \\
\text { Hasanah } \\
\text { Azmi } \\
\end{array}$ & 90 & 80 & 80 & 80 & 80 & 85 & 80 \\
\hline 17 & $\begin{array}{l}\text { Lupi } \\
\text { Nugraha }\end{array}$ & 80 & 80 & 80 & 90 & 80 & 80 & 80 \\
\hline 18 & $\begin{array}{l}\text { Muhammad } \\
\text { Lutfi } \\
\text { Qairawan }\end{array}$ & 80 & 90 & 85 & 85 & 85 & 85 & 80 \\
\hline 19 & $\begin{array}{l}\text { Aep } \\
\text { Syaipudin }\end{array}$ & 80 & 90 & 85 & 80 & 85 & 85 & 80 \\
\hline 20 & $\begin{array}{l}\text { Hamzah } \\
\text { Syahid } \\
\text { Abdillah }\end{array}$ & 85 & 90 & 85 & 75 & 75 & 85 & 80 \\
\hline 21 & $\begin{array}{l}\text { Rachmad } \\
\text { Andi }\end{array}$ & 90 & 85 & 80 & 75 & 75 & 75 & 80 \\
\hline 22 & $\begin{array}{l}\text { Endar } \\
\text { Sunandar }\end{array}$ & 85 & 80 & 80 & 80 & 90 & 75 & 85 \\
\hline 23 & Rahayu & 80 & 80 & 90 & 90 & 90 & 80 & 90 \\
\hline 24 & $\begin{array}{l}\text { Nurul } \\
\text { Khaeriyah }\end{array}$ & 80 & 80 & 90 & 75 & 85 & 75 & 85 \\
\hline 25 & Arif Rahman & 85 & 80 & 90 & 75 & 80 & 75 & 80 \\
\hline
\end{tabular}

Sumber: (Agustini \& Ariska, 2018)

\section{Melakukan Normalisasi}

Selanjutnya menghitung proses normalisasi keputusan (R) ke suatu skala yang dapat diperbandingkan dengan semua rating alternatif yang ada. Dimana diambil berdasarkan nilai kriteria terbesar dari masing alternatif.Rumus nilai normalisasi diambil berdasarkan

$$
R=\frac{\text { Nilai Karyawan }}{\text { Max (Nilai per Kriteria }}
$$

Sehingga didapat nilai sebagai berikut:

Tabel.4 Data Normalisasi Kriteria Perilaku

\begin{tabular}{clc}
\hline No & \multicolumn{1}{c}{ Nama } & Nilai C1 \\
\hline 1 & Karyadi & 1 \\
\hline 2 & Meiga Wati Herlina & 0.95 \\
\hline 3 & Harmi Syaputra & 0.95 \\
\hline 4 & Hanifah Andini & 0.84 \\
\hline 5 & Arif Rahman & 0.95
\end{tabular}




\begin{tabular}{lll}
\hline 6 & Ujang Sadili & 0.84 \\
\hline 7 & Muhammad Hilman Rifqi & 0.89 \\
\hline 8 & Haryuda & 0.89 \\
\hline 9 & Reni Kurnia & 0.95 \\
\hline 10 & Imam Mustaqim & 0.84 \\
\hline 11 & Arman Maulana & 0.84 \\
\hline 12 & Esa Nur Khaerurrizal & 0.84 \\
\hline 13 & Firdaus & 0.89 \\
\hline 14 & Faiz Abdillah & 0.84 \\
\hline 15 & Anita Hermawati & 0.84 \\
\hline 16 & Annisa UI Hasanah Azmi & 0.95 \\
\hline 17 & Lupi Nugraha & 0.84 \\
\hline 18 & Muhammad Lutfi Qairawan & 0.84 \\
\hline 19 & Aep Syaipudin & 0.84 \\
\hline 20 & Hamzah Syahid Abdillah & 0.89 \\
\hline 21 & Rachmad Andi & 0.95 \\
\hline 22 & Endar Sunandar & 0.89 \\
\hline 23 & Rahayu & 0.84 \\
\hline 24 & Nurul Khaeriyah & 0.84 \\
\hline 25 & Muhammad Husuf & 0.89 \\
\hline
\end{tabular}

Sumber: (Agustini \& Ariska, 2018)

Normalisasi dilakukan pada setiap kriteria yang suda ditentukan sehingga Pada tabel tiap kriteria yang ada dapat dihasilkan nilai normalisasi tertinggi adalah 1.00 yaitu Karyadi, M. Hilman Rifqi, Imam Mustaqim, Endar Sunandar, Rahayu dan Muhammad Husuf. Nilai maksimal pada kriteria Penerapan Pekerjaan adalah 90. Sebagai contoh dari perhitungan sesuai dengan rumus normalisasi dari SAW, dari nilai Karyadi adalah sebagai berikut:

\begin{tabular}{|c|c|}
\hline Kriteria $(R)$ & Nilai Karyawan \\
\hline & $\kappa=\overline{\text { Max Nilai per Kriteria }}$ \\
\hline Perilaku & $P-95$ \\
\hline & $\begin{array}{c}R=\overline{95} \\
R=1\end{array}$ \\
\hline Inisiatif & $P-85$ \\
\hline & $\begin{array}{c}K=\overline{90} \\
R=0.94\end{array}$ \\
\hline Kerjasama & $R=\underline{95}$ \\
\hline & $\begin{array}{l}R=\overline{95} \\
R=1\end{array}$ \\
\hline Disiplin & $R=\frac{90}{2}$ \\
\hline & $\begin{array}{c}R=\overline{90} \\
R=1\end{array}$ \\
\hline Loyalitas & $R=\frac{90}{-}$ \\
\hline & $\begin{array}{c}R=\overline{90} \\
R=1\end{array}$ \\
\hline Komitmen & $R=\frac{95}{0 r}$ \\
\hline & $R=1$ \\
\hline Kreatifitas & $R=\frac{95}{95}$ \\
\hline & $R=1$ \\
\hline Tanggung & $R=\frac{90}{n}$ \\
\hline Jawab & $\begin{array}{l}R=\overline{90} \\
R=1\end{array}$ \\
\hline
\end{tabular}

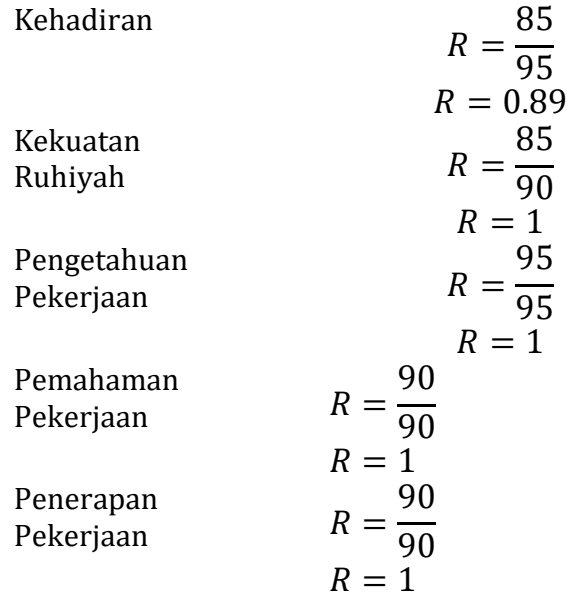

4. Melakukan Perangkingan

Langkah terakhir adalah menghitung nilai bobot dari masing-masing nilai alternatif berdasarkan nilai kriteria dan bobot menggunakan persamaan:

$$
X=\text { Nilai Normalisasi } x \text { Nilai Bobot }
$$

Dimana nilai bobot adalah sebagai berikut: Tabel 5. Nilai Bobot Perangkingan

\begin{tabular}{llcc}
\hline \multicolumn{1}{c}{ Sub Aspek } & Kriteria & Keterangan & $\begin{array}{c}\text { Nilai } \\
\text { Bobot }\end{array}$ \\
\hline Perilaku & C1 & Penting & 0,75 \\
\hline Inisiatif & C2 & Penting & 0,75 \\
\hline Kerjasama & C3 & $\begin{array}{c}\text { Sangat } \\
\text { Penting }\end{array}$ & 0,90 \\
\hline Lisiplin & C4 & Penting & 0,75 \\
\hline Komititas & C5 & $\begin{array}{c}\text { Sanagt } \\
\text { Penting }\end{array}$ & 0,90 \\
\hline Kreatifitas & C6 & $\begin{array}{c}\text { Sangat } \\
\text { Penting }\end{array}$ & 0,90 \\
\hline Tanggung Jawab & C7 & Penting & 0,75 \\
\hline Kehadiran & C9 & $\begin{array}{c}\text { Sangat } \\
\text { Penting }\end{array}$ & 0,90 \\
\hline Kekuatan Ruhiyah & C10 & $\begin{array}{c}\text { Penting } \\
\text { Penting }\end{array}$ & 0,75 \\
\hline $\begin{array}{l}\text { Pengetahuan } \\
\text { Pekerjaan }\end{array}$ & C11 & $\begin{array}{c}\text { Sanagt } \\
\text { Penting }\end{array}$ & 0,90 \\
\hline Pemahaman Pekerjaan & C12 & $\begin{array}{c}\text { Sangat } \\
\text { Penting }\end{array}$ & 0,90 \\
\hline Penerapan Pekerjaan & C13 & $\begin{array}{c}\text { Sangat } \\
\text { Penting }\end{array}$ & 0,90 \\
\hline Sumber: Agustini dan Arisk & C & 0180 \\
\hline
\end{tabular}

Sumber: Agustini dan Ariska (2018)

5. Perbaandingan Nilai Manual dengan FSAW

Perhitungan dengan manual dilakukan dengan cara menjumlahkan seluruh kriteria ilai kemudian dibagi dengan total jumlah kriteria dan rumusnya dapat dilihat dibawah ini:

$$
\begin{aligned}
& \text { Nilai }= \\
& \frac{C 1 C 2 C 3 C 4 C 5 C 6 C 7 C 8 C 9 C 10 C 11 C 12 C 13}{13}
\end{aligned}
$$

Sehingga didapatkan hasil perhitungan dibawah ini: 
Tabel 6. Perangkingan dari perhitungan FSAW

\begin{tabular}{|c|c|c|c|c|c|c|c|c|c|}
\hline & & \multicolumn{7}{|c|}{ NILAI } & \multirow[b]{2}{*}{ TOTAL } \\
\hline NO & NAMA & $\mathrm{C} 1$ & $\mathrm{C} 2$ & & & $\mathrm{C} 4$ & $\mathrm{C} 5$ & C6 & \\
\hline 1 & Karyadi & 0.8 & & 0.71 & 0.9 & 0.8 & 90 & 0.9 & 10.73 \\
\hline 2 & Rahayu & 0.6 & & 0.67 & 0.85 & 0.8 & 0.9 & 0.9 & 10.37 \\
\hline 3 & M. Hilman Rifqi & 0.7 & & 0.71 & 0.85 & 0.7 & 0.9 & 0.9 & 10.19 \\
\hline 4 & Meiga Wati Herlina & 0.7 & & 0.75 & 0.85 & 0.7 & 0.9 & 0.9 & 10.19 \\
\hline 5 & Imam Mustaqim & 0.6 & & 0.67 & 0.81 & 0.7 & 0.9 & 0.9 & 10.07 \\
\hline 6 & Aep Syaipudin & 0.6 & & 0.75 & 0.81 & 0.7 & 0.9 & 0.9 & 10.06 \\
\hline 7 & Reni Kurnia & 0.7 & & 0.67 & 0.85 & 0.7 & 0.9 & 0.9 & 10.02 \\
\hline 8 & Nurul Khaeriyah & 0.6 & & 0.67 & 0.85 & 0.6 & 0.9 & 0.8 & 9.96 \\
\hline 9 & $\begin{array}{l}\text { Hamzah Syahid } \\
\text { Abdillah }\end{array}$ & 0.7 & & 0.75 & 0.81 & 0.6 & 0.8 & 0.9 & 9.95 \\
\hline 10 & M. Lutfi Qairawan & 0.6 & & 0.75 & 0.81 & 0.7 & 0.9 & 0.9 & 9.95 \\
\hline 11 & Muhammad Husuf & 0.7 & & 0.67 & 0.85 & 0.6 & 0.8 & 0.8 & 9.87 \\
\hline 12 & Endar Sunandar & 0.7 & & 0.67 & 0.76 & 0.7 & 0.9 & 0.8 & 9.84 \\
\hline 13 & Arman Maulana & 0.6 & & 0.67 & 0.76 & 0.7 & 0.8 & 0.9 & 9.78 \\
\hline 14 & Esa Nur Khaerurrizal & 0.6 & & 0.67 & 0.76 & 0.7 & 0.8 & 0.9 & 9.78 \\
\hline 15 & Arif Rahman & 0.7 & & 0.67 & 0.76 & 0.7 & 0.9 & 0.9 & 9.78 \\
\hline 16 & $\begin{array}{l}\text { Annisa UI } \\
\text { Hasanah Azmi } \\
\end{array}$ & 0.7 & & 0.67 & 0.76 & 0.7 & 0.8 & 0.9 & 9.76 \\
\hline 17 & Haryuda & 0.7 & & 0.67 & 0.85 & 0.7 & 0.9 & 0.9 & 9.76 \\
\hline 18 & Faiz Abdillah & 0.6 & & 0.67 & 0.76 & 0.6 & 0.8 & 0.9 & 9.73 \\
\hline 19 & Firdaus & 0.7 & & 0.67 & 0.76 & 0.8 & 0.8 & 0.9 & 9.71 \\
\hline 20 & Harmi Syaputra & 0.7 & & 0.67 & 0.76 & 0.7 & 0.8 & 0.9 & 9.7 \\
\hline 21 & Lupi Nugraha & 0.6 & & 0.67 & 0.76 & 0.8 & 0.8 & 0.9 & 9.69 \\
\hline 22 & Anita Hermawati & 0.6 & & 0.67 & 0.76 & 0.7 & 0.8 & 0.9 & 9.66 \\
\hline 23 & Rachmad Andi & 0.7 & & 0.71 & 0.76 & 0.6 & 0.8 & 0.8 & 9.59 \\
\hline
\end{tabular}

Sumber : (Agustini \& Ariska, 2018)

Pada tabel diatas yang mendapatkan ranking 1 adalah Karyadi dengan nilai 10.73.Selanjutnya dapat dilihat hasil perbandingan

perankingan antara perankingan manual dan FSAW sebagai berikut:

Tabel 7. Hasil Perbandingan perhitungan manual dengan FSAW

\begin{tabular}{|c|c|c|c|c|c|c|}
\hline NO. & NAMA & TOTAL MANUAL & $\begin{array}{l}\text { PERINGKA } \\
\text { T MANUAL }\end{array}$ & NAMA & TOTAL FSAW & $\begin{array}{l}\text { PERINGKAT } \\
\text { FSAW }\end{array}$ \\
\hline 1 & Karyadi & 1160 & 1 & Karyadi & 10.73 & 1 \\
\hline 2 & Rahayu & 1120 & 2 & Rahayu & 10.37 & 2 \\
\hline 3 & Meiga Wati Herlina & 1100 & 3 & M. Hilman Rifqi & 10.19 & 3 \\
\hline 4 & M. Hilman Rifqi & 1100 & 4 & Meiga Wati Herlina & 10.19 & 4 \\
\hline 5 & Reni Kurnia & 1085 & 5 & Imam Mustaqim & 10.07 & 5 \\
\hline 6 & Imam Mustaqim & 1085 & 6 & Aep Syaipudin & 10.06 & 6 \\
\hline 7 & Aep Syaipudin & 1085 & 7 & Reni Kurnia & 10.02 & 7 \\
\hline 8 & M. Lutfi Qairawan & 1080 & 8 & Nurul Khaeriyah & 9.96 & 8 \\
\hline 9 & Hamzah Syahid A & 1075 & 9 & Hamzah Syahid A & 9.95 & 9 \\
\hline 10 & Nurul Khaeriyah & 1075 & 10 & M. Lutfi Qairawan & 9.95 & 10 \\
\hline 11 & Endar Sunandar & 1065 & 11 & Muhammad Husuf & 9.87 & 11 \\
\hline 12 & Muhammad Husuf & 1065 & 12 & Endar Sunandar & 9.84 & 12 \\
\hline 13 & Arif Rahman & 1060 & 13 & Arman Maulana & 9.78 & 13 \\
\hline 14 & Haryuda & 1055 & 14 & Esa Nur Khaerurrizal & 9.78 & 14 \\
\hline 15 & Arman Maulana & 1055 & 15 & Arif Rahman & 9.78 & 15 \\
\hline 16 & Esa Nur Khaerurrizal & 1055 & 16 & Annisa UI Hasanah A & 9.76 & 16 \\
\hline 17 & Annisa UI Hasanah A & 1055 & 17 & Haryuda & 9.76 & 17 \\
\hline 18 & Harmi Syaputra & 1050 & 18 & Faiz Abdillah & 9.73 & 18 \\
\hline 19 & Firdaus & 1050 & 19 & Firdaus & 9.71 & 19 \\
\hline 20 & Faiz Abdillah & 1050 & 20 & Harmi Syaputra & 9.7 & 20 \\
\hline 21 & Lupi Nugraha & 1050 & 21 & Lupi Nugraha & 9.69 & 21 \\
\hline 22 & Anita Hermawati & 1045 & 22 & Anita Hermawati & 9.66 & 22 \\
\hline 23 & Rachmad Andi & 1040 & 23 & Rachmad Andi & 9.59 & 23 \\
\hline 24 & Ujang Sadili & 1030 & 24 & Ujang Sadili & 9.52 & 24 \\
\hline 25 & Hanifah Andini & 1025 & 25 & Hanifah Andini & 9.48 & 25 \\
\hline
\end{tabular}

Sumber : (Agustini \& Ariska, 2018)

Dari hasil diatas dapat dilihat perbandingan dengan cara perhitungan manual dengan FSAW dimana Karyadi mendapatkan nilai 1160 dengan peringkat pertama pada perhitungan manual 
sedangkan dengan metode Fuzzy SAW mendapatkan nilai 10.73 sehingga mendapatkan nilai tertinggi dan peringkat pertama sebagai karyawan terbaik.

Pada perhitungan dengan metode FSAW seluruh kriteria diberikan bobot, jadi jika ada kekurangan disalah satu kriteria tetapi bobotnya kecil maka tidak terlalu berpengaruh untuk penilaian, begitu juga sebaliknya jika bobot kriterianya besar tetapi nilnya kecil maka akan sangat berpengaruh terhadap perankingan. Jika dengan cara manual setiap kriteria tidak memiliki bobot sehingga jika ada nilai salah satu kriteria yang kecil masih bisa dibantu dengan nilai lainnya, misal nilai pada aspek sikap kerja kecil tetapi nilai hasil kerja tinggi maka nilai aspek hasil kerja akan dipakai untuk nilai sikap kerja, jadi disini letak kekurangan penilaian manual.

\section{KESIMPULAN}

Berdasarkan penelitian yang dilakukan oleh penulis didapat beberapa kesimpulannya diantaranya sebagai berikut:Penilaian kinerja karyawan menggunakan metode FSAW jika bobot kriteria besar tetapi nilainya kecil akan sangat berpengaruh untuk penilaian tetapi jika ada kekurangan pada salah satu kriteria yang bobotnya kecil maka tidak terlalu berpengaruh untuk penilaian. Penilaian kinerja karyawan pada DTPeduli Bekasi dengan beberapa aspek kriteria menggunakan model Fuzzy Simple Additive Weighting (FSAW) sudah berjalan dengan baik dan dapat menghasilkan pembobotan kriteria penilaian dan informasi yang jelas dan cepat dibandingkan dengan perhitungan secara manual sehingga Kepala Cabang DTPeduli Bekasi dapat mempergunakannya sebagai alat bantu pengambilan keputusan yang tepat dalam pengambilan keputusan penilaian kinerja karyawan di DTPeduli Bekasi. Berdasarkan hasil penelitian diatas, posisi peringkat pertama dan kedua pada perhitungan manual dan perhitungan dengan metode FSAW menunjukkan nama yang sama, sedangkan karyawan dengan nama Meiga Wati Herlina mendapatkan nilai 1100 dengan peringkat ketiga pada perhitungan manual sedangkan dengan metode FSAW mendaptkan peringkat keempat.

\section{REFERENSI}

Abadi, S., \& Latifah, F. (2016). DECISION SUPPORT SYSTEM PENILAIAN KINERJA KARYAWAN PADA PERUSAHAAN MENGGUNAKAN METODE SIMPLE ADDITIVE WEIGHTING Satria Abadi , Febriani Latifah, 6, 37-43.
Agustini, F., \& Ariska, E. R. (2018). Laporan Akhir Penelitian Mandiri STMIK Nusa Mandiri Jakarta.

Ardila, N. D., \& Pramusinto, H. (2015). Pengaruh kepemimpinan, komunikasi internal, dan motivasi kerja terhadap kinerja pegawai bp3akb provinsi jawa tengah, $X(1), 53-66$.

Djamain, Y., \& Christin, H. De. (2015). Sistem Pendukung Keputusan Penerimaan Pegawai Baru PT.PLN (Persero) Kantor Pusat dengan Menggunakan Metode Simple Additive Weighting (SAW),tle. Teknik Iformatika, 8, 39-47.

Khairul, K., Pembangunan, U., Budi, P., Putera, A., Siahaan, U., Pembangunan, U., \& Budi, P. (2016). Decision Support System in Selecting The Appropriate Laptop Using Simple Additive Weighting, (December).

Mudayana, A. A. (2013). Pengaruh motivasi dan beban kerja terhadap kinerja karyawan di rumah sakit nur hidayah bantul. Jurnal Kesehatan Masyarakat, 84-91.

Rusdi, I. (2015). KELULUSAN PESERTA PRAJABATAN MENGGUNAKAN SIMPLE ADDITIVE WEIGHTING PADA PUSAT. Jurnal Techno Nusa Mandiri, XII(1), 64-68.

Rusdiansyah. (2017). SEKOLAH MENENGAH KEJURUAN DENGAN METODE SIMPLE. Jurnal Techno Nusa Mandiri, XIV(1), 49-56.

Sheyla Feby Liesdiana, P. M. (2017). Sistem Pendukung Keputusan Penentuan Kontrak Kerja Agent Call Center Menggunakan. Jurnal Informatika, 4(1), 76-81.

Siprianus Endro Sri Widodo, Septia Lutfi, S. (2014). Sistem Pendukung Keputusan Penilaian Kinerja Karyawan Menggunakan Metode Simple Additive Weighting (SAW) Pada PT. Indonesia Steel Tube Work Oleh.

Susanti, M. I., \& Wasiyanti, S. (2017). Metode Simple Additive Weighting ( Saw ) Dalam Penentuan Pemberian Beasiswa Pada Siswa Sekolah Menengah Atas, 5(2), 114-123.

Yahya, A., \& Yudihartanti, Y. (n.d.). Sistem Penilaian dan Perankingan Karyawan pada Radar Banjarmasin dengan Menggunakan Metode Simple Additive Weighting. 